\title{
MAGILL CIRCUIT AND CONTROLLED VENTILATION
}

\author{
M.O. Obiaya and P. Dakaraju
}

\section{INTRODUCTION}

The Magill circuit is extensively used in Anaesthesia. The gas exchange characteristics have been well studied ${ }^{1,2,3}$ and the classical teaching is that it is the most economical system for spontaneous ventilation but unsuitable for controlled ventilation. However, in clinical practice, especially in developing countries, situations do occur where the use of Magill attachment for intermittent positive pressure ventilation is inevitable. These situations include: the absence of soda lime, the absence of apparatus for a closed circuit, the absence of unidirectional valve, and the availability of trilene or halothane as the only inhalational agent at caesarean sections.

The Magill attachment may then be used on these occasions for controlled ventilation. It is recommended that for this purpose a very large flow of gases is necessary to prevent rebreathing and the retention of $\mathrm{CO}_{2}$. Using a model lung Sykes $^{4}$ found that impracticably high flows were necessary to eliminate rebreathing and $\mathrm{CO}_{2}$ retention and advised against the use of the system for IPPV. But Marshal and Henderson ${ }^{5}$ used various patterns of ventilation and were able to keep $\mathrm{CO}_{2}$ within limits comparable to those found during normal sleep, using a flow of fresh gases as low as $51 / \mathrm{min}$. Their studies were conducted under regulated conditions. Respiratory volumes were measured and varied to study corresponding changes in $\mathrm{CO}_{2}$ level. The present study was planned to estimate gas changes in patients ventilated with a Magill attachment in conditions that occur in normal clinical practice. No attempt was made to measure respiratory volumes (tidal or minute). The anaesthetist relied entirely on his training to produce adequate ventilation.

\section{Method and Material}

Eighteen Nigerians who came to the University of Benin Teaching Hospital for various surgical conditions were included in the study. Nine patients were ventilated artificially and the other nine were used as a control group. Before operation all patients were examined to exclude any respiratory or cardiovascular disease. Chest X-rays were done to confirm the absence of cardio-respiratory disease. The patients were premedicated with either atropine $0.6 \mathrm{mg}$ and pethidine 50-100 $\mathrm{mg}$ or omonopon $20 \mathrm{mg}$ and scopolamine $0.4 \mathrm{mg}$. An arterial blood sample was taken from the femoral artery in a heparinized syringe just before induction. The sample was then sent to the laboratory in ice packs for blood gas analysis. The patient was induced with a sleep dose of thiopentone ( 2.5 per cent sol.) intra-

Department of Anaesthesiology, University of Benin, Benin City, Nigeria. 


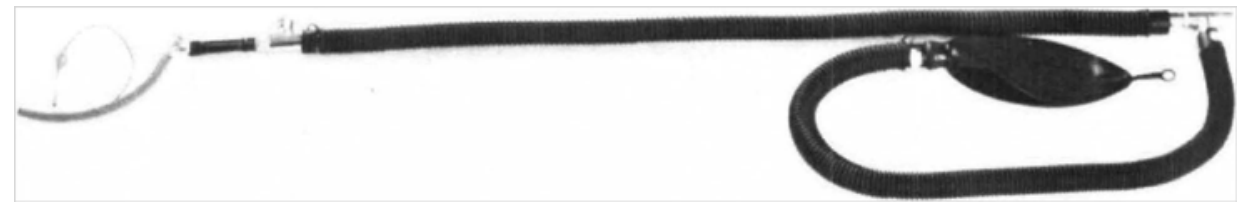

Figure 1. Magill attachment with the reservoir bag extended for ease of manual ventilation.

venously, $40 \mathrm{mg}$ base of suxamethonium bromide was given intravenously and the trachea was intubated. The patient was then connected to the anaesthetic machine through a Magill attachment and given oxygen ( $31 / \mathrm{min}$ ) and nitrous oxide $(6 \mathrm{l} / \mathrm{min})$ and was gently assisted manually until spontaneous respiration returned. Halothane was then added as required. An indwelling cannula was introduced into the radial artery and the patient was taken into the theatre for operation. The patient was paralysed with curare $30 \mathrm{mg}$ and IPPV was instituted using a slightly modified Magill attachment for ease of manual ventilation (Figure 1). Further arterial blood samples were taken every five minutes for $30 \mathrm{~min}$ and then every $15 \mathrm{~min}$ for one hour if the operation lasted so long.

The gas flow remained at $31 / \mathrm{min}$ of oxygen and $6 \mathrm{l} / \mathrm{min}$ of nitrous oxide throughout the sampling period. Halothane 0.5 per cent was added as needed. Manual ventilation was by trained anaesthetists of the level of registrars (at least two years' training) and above. No attempt was made to control the ventilatory volumes.

Patients in the control group were treated in the same manner except that curare was not given and ventilation was spontaneous throughout. The inhalational agent was either trilene or halothane. Blood samples were analysed using the CorningEel 165 apparatus. The machine was standardized with gases from disposable cylinders prepared by the Corning Company.

\section{RESULT}

The patients used for the study included four males and five females. The ages ranged between 19 years and 46 years and the indications for operation were as shown in Table I. Age and sex distribution and indication for operation for the control group are shown in Table II.

Results of blood gas analysis showed that the $\mathrm{Pa}_{\mathrm{CO}_{2}}$ in the controlled group was within normal limits throughout the period of sampling. Mean values ranged between $39.6 \mathrm{~mm} \mathrm{Hg}$ and 42.4 with an overall mean of $40.5 \mathrm{~mm} \mathrm{Hg}$. Values for the control group were higher with an overall mean of $43.3 \mathrm{~mm} \mathrm{Hg}$. Although the difference was not statistically significant, patients breathing spontaneously showed a definite tendency to higher $\mathrm{Pa}_{\mathrm{CO}_{2}}$. 
TABLE I

Age and Sex Distribution for Patients on IPPV AND INDICATIONS FOR OPERATION

\begin{tabular}{|c|c|c|c|c|c|}
\hline \multicolumn{3}{|c|}{ Male } & \multicolumn{3}{|c|}{ Female } \\
\hline Name & $\begin{array}{c}\text { Age } \\
\text { (years) }\end{array}$ & $\begin{array}{l}\text { Indications } \\
\text { for operation }\end{array}$ & Name & $\begin{array}{c}\text { Age } \\
\text { (years) }\end{array}$ & $\begin{array}{l}\text { Indications } \\
\text { for operation }\end{array}$ \\
\hline P.J. & 19 & R.I.H. & I.E. & 19 & R.I.H. \\
\hline U.A. & 20 & R.I.H. & $\mathrm{O}, \mathrm{M}$ & 25 & $\begin{array}{l}\text { Vagotomy } \\
\text { and } \\
\text { pyloroplasty }\end{array}$ \\
\hline A.F. & 25 & R.I.H. & M.N. & 30 & $\begin{array}{l}\text { Vagotomy } \\
\text { and } \\
\text { pyloroplasty }\end{array}$ \\
\hline \multirow[t]{2}{*}{ O.E. } & \multirow[t]{2}{*}{40} & \multirow{2}{*}{$\begin{array}{l}\text { Bilateral } \\
\text { inguinal } \\
\text { hernia }\end{array}$} & A.A. & 40 & $\begin{array}{l}\text { Total } \\
\text { hysterectomy }\end{array}$ \\
\hline & & & A.J. & 46 & Laparotomy \\
\hline
\end{tabular}

TABLE II

Age and Sex Distribution of Patients who inere on Spontaneous VENTILATION AND INDICATIONS FOR OPERATION

\begin{tabular}{|c|c|c|c|c|c|}
\hline \multicolumn{3}{|c|}{ Male } & \multicolumn{3}{|c|}{ Female } \\
\hline Name & $\begin{array}{c}\text { Age } \\
\text { (years) }\end{array}$ & $\begin{array}{c}\text { Indications } \\
\text { for operation }\end{array}$ & Name & $\begin{array}{c}\text { Age } \\
\text { (years) }\end{array}$ & $\begin{array}{r}\text { Indications } \\
\text { for operation }\end{array}$ \\
\hline 0.0 & 25 & R.I.H. & I.E. & 19 & R.I.H. \\
\hline M.M. & 34 & $\begin{array}{l}\text { Hydroco- } \\
\text { electomy }\end{array}$ & L.E. & 19 & $\begin{array}{l}\text { Cervical } \\
\text { laceration }\end{array}$ \\
\hline A.O. & 40 & R.I.H. & $\mathrm{O} . \mathrm{M}$ & 25 & R.I.H. \\
\hline O.E. & 40 & $\begin{array}{l}\text { Bilateral } \\
\text { herniorrhaphy }\end{array}$ & E.A. & 35 & $\begin{array}{l}\text { Bilateral } \\
\text { inguinal }\end{array}$ \\
\hline E.J. & $4 \tilde{5}$ & L.I.H. & & & \\
\hline
\end{tabular}

The mean $\mathrm{pH}$ for patients in the controlled group was 7.41. Patients breathing spontaneously were more acidotic with a mean $\mathrm{pH}$ of 7.31 .

\section{Discussion}

Mapleson ${ }^{1}$ analysed the delivery characteristics of the Magill attachment. He showed that at inspiration the lungs were inflated and at the same time fresh gas was expelled through the expiratory valve. At expiration, dead space gas and alveolar gas returned into the system without any further loss through the expiratory valve. At the next squeezing of the bag, some alveolar gas and dead space gas is driven through the expiratory valve. Some of the alveolar gas is, however, returned to the patient. There is, therefore, always some rebreathing with controlled ventilation. Expulsion of gas from the system takes place only in the inspiratory phase. This requires that for maximum $\mathrm{CO}_{2}$ elimination as much as possible of 
CANADIAN ANAESTHETISTS' SOCIETY JOURNAL
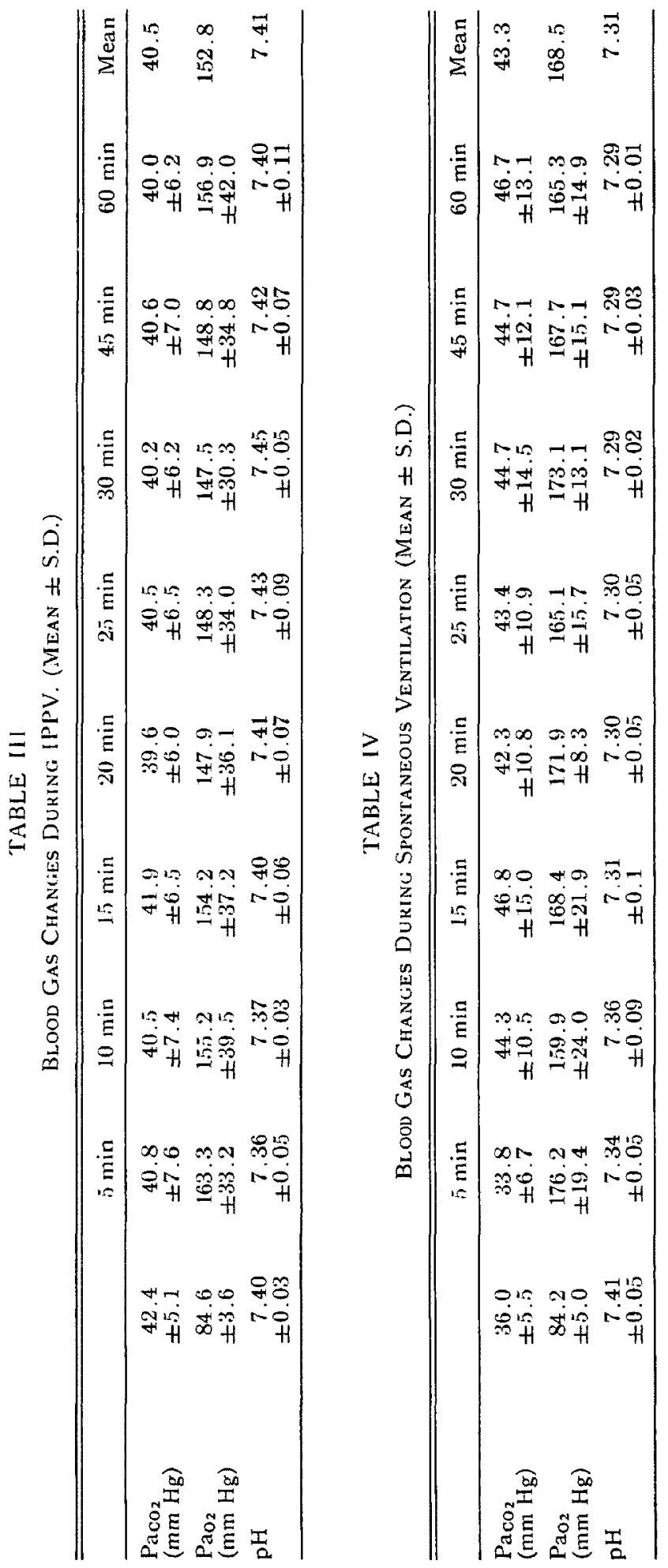


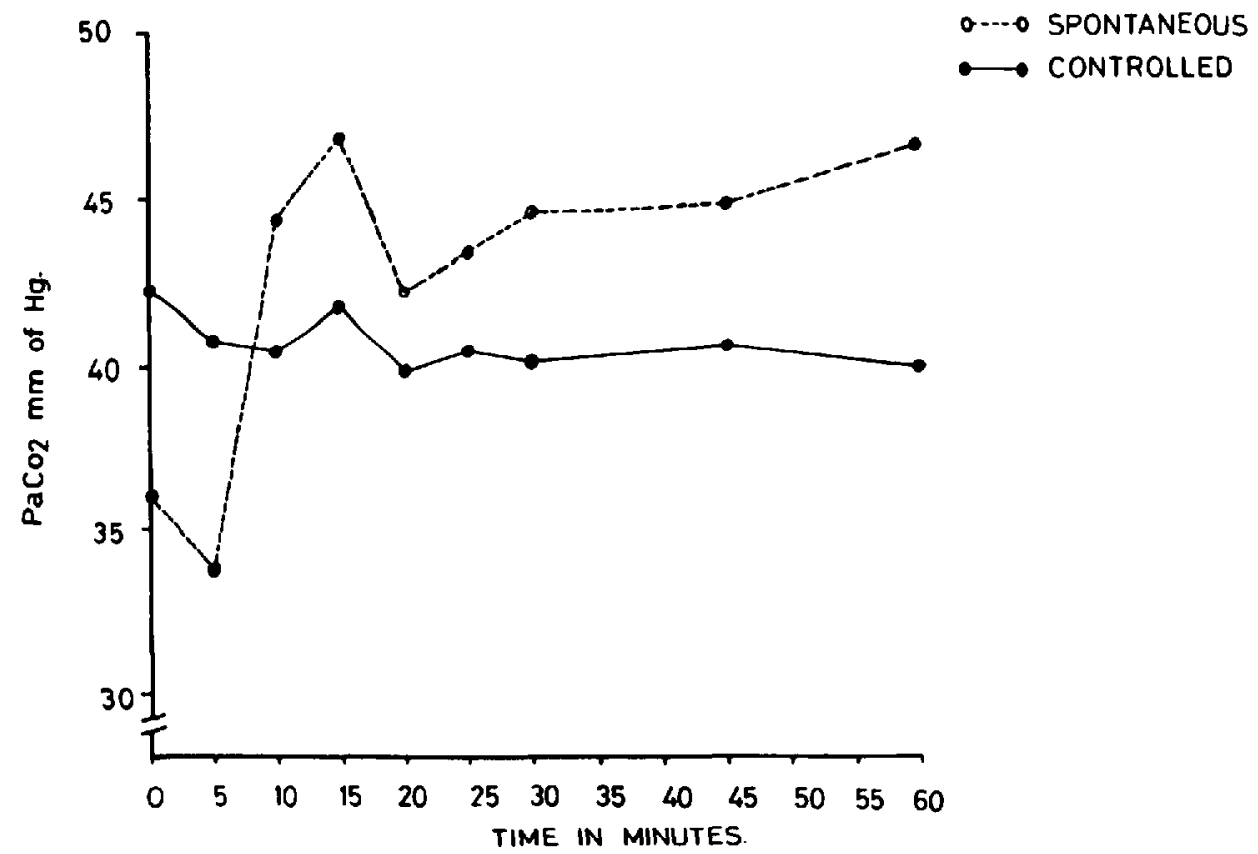

Frgure 2. Paca, changes in spontaneous and controlled ventilation using the Magill circuit.

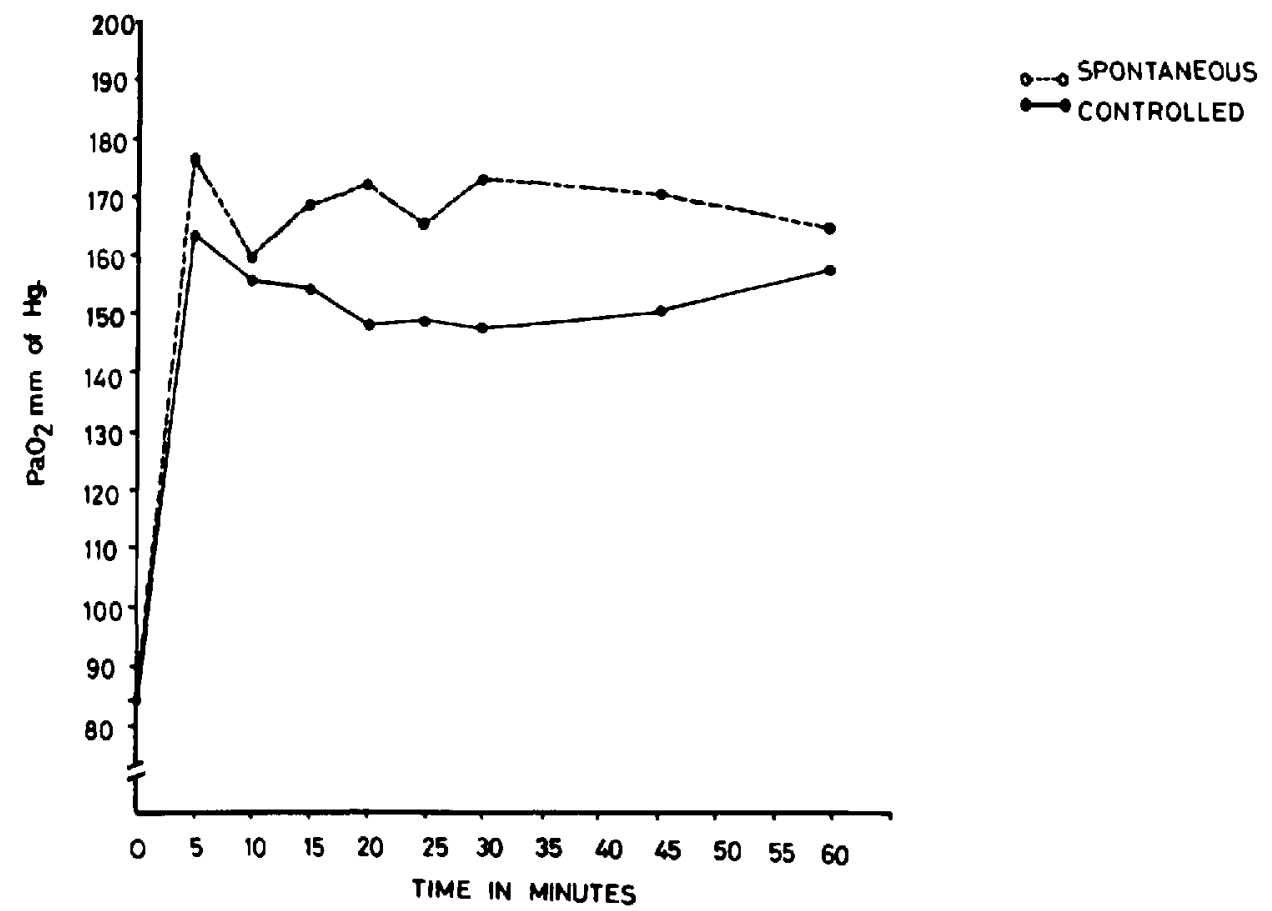

Ficune 3. $\mathrm{Pa}_{\mathrm{o}}$ changes in spontaneous and controlled ventilation using the Magill circuit. The lower $\mathrm{Pao}_{\text {. }}$ for controlled ventilation is probably due to a certain amount of rebreathing (see text) and a consequent lower $\mathrm{Plo}_{\mathrm{O}_{2}}$. 
the alveolar gas should return into the corrugated tube beyond the expiratory valve during the expiratory phase. With the rise of pressure at the next inspiratory phase, this gas will then be expelled through the expiratory valve, although some of it must flow into the lung because of the low pressure in the lung at the beginning of inspiration. Mapleson ${ }^{1}$ suggested that a high gas flow is necessary to achieve adequate elimination of carbon dioxide. But Marshal and Henderson ${ }^{5}$ have shown that adequate elimination of $\mathrm{CO}_{2}$ can be achieved using low gas flows. Results in our series equally confirm adequate $\mathrm{CO}_{2}$ elimination with a flow of $9 \mathrm{l} / \mathrm{min}$. This probably means that there must be longitudinal mixture along the corrugated tube permitting enough of alveolar gas into the tube during the expiratory phase. Marshal and Henderson ${ }^{5}$ in fact found that there was fairly even mixing of gases throughout the ventilated alveolar space and the anaesthetic system and hence regarded all as constituting one system.

Another important factor must be the lung characteristics of the patient. The elastic recoil of the lungs and chest wall during the expiratory phase must be adequate and the return to the resting position must be completed within a reasonable time so that maximum expulsion of alveolar gas can take place within the available time. It is reasonable to assume that elderly patients and emphysematous patients with fairly rigid chest wall will have $\mathrm{CO}_{2}$ retention when controlled with the Magill circuit, unless very high flows are used. The mean $\mathrm{Pa}_{\mathrm{CO}_{2}}$ of 40.5 $\mathrm{mm} \mathrm{Hg}$ was higher than is normally obtained in controlled ventilation. Computing figures from other workers including his own, $\mathrm{Nunn}^{6}$ showed that $\mathrm{Pa}_{\mathrm{CO}_{2}}$ in artificially ventilated patients ranged between 25 and $35 \mathrm{~mm} \mathrm{Hg}$. A deliberate attempt is usually made to reduce the level of $\mathrm{Pa}_{\mathrm{CO}_{2}}$ to ensure respiratory alkalosis with the aim of avoiding the dangers of respiratory acidosis. However many workers have reported the dangers of prolonged hypocarbia. These include the depletion of $\mathrm{CO}_{2}$ stores which, with the return of spontantous ventilation, may lead to hypoxaemia when breathing air. ${ }^{7}$ Cerebral circulation is reduced and this may lead to harmful effects. ${ }^{8,9}$ Maintaining $\mathrm{Pa}_{\mathrm{CO}_{2}}$ therefore around the physiological normal of $40 \mathrm{~mm} \mathrm{Hg}$ ensures adequate cerebral perfusion and removes the danger of extreme respiratory alkalosis which attends severe hyperventilation.

With an inspired oxygen concentration of about $33 \frac{1}{3}$ per cent and a mean $\mathrm{Pa}_{\mathrm{CO}_{2}}$ of $40.5 \mathrm{~mm} \mathrm{Hg}$, the calculated alveolar oxygen tension $\left(\mathrm{P}_{\mathrm{A}_{2}}\right)$ should be about $202.4 \mathrm{~mm} \mathrm{Hg}$. Our mean $\mathrm{Pa}_{\mathrm{O}_{2}}$ was $152.8 \mathrm{~mm} \mathrm{Hg}$ giving an approximate alveolararterial oxygen tension difference of $49.6 \mathrm{~mm} \mathrm{Hg}$. (A more accurate value may be lower than this as the existence of some rebreathing will no doubt reduce the $\mathrm{PI}_{\mathrm{O}_{2}}$ and hence the $\mathrm{P}_{\mathrm{A}_{2}}$ ). The raised $\mathrm{A}-\mathrm{a} \mathrm{Po}_{2}$ difference under anaesthesia is in keeping with similar findings by other workers. Campbell, Nunn and Peckett ${ }^{10}$ reported an increase in $\mathrm{A}-\mathrm{a} \mathrm{P}_{\mathrm{O}_{2}}$ difference under anaesthesia the gradient being dependent on the inspired oxygen concentration. Colgan and Whang ${ }^{11}$ had a mean $\mathrm{A}-\mathrm{a} \mathrm{P}_{\mathrm{O}_{2}}$ difference of $164 \mathrm{~mm} \mathrm{Hg}$ in patients breathing 100 per cent oxygen. Marshal, et al. ${ }^{12}$ had a $\mathrm{PA}_{\mathrm{O}}-\mathrm{Pa}_{\mathrm{O} g}$ gradient of $170 \mathrm{~mm} \mathrm{Hg}$ rising to $218 \mathrm{~mm} \mathrm{Hg}$ at the end of the operation in patients breathing 100 per cent oxygen. Panday and Nunn ${ }^{13}$ were unable to reduce the $\mathrm{A}-\mathrm{a} \mathrm{P}_{\mathrm{O}_{2}}$ difference even when applying airway pressures of over $30 \mathrm{~cm} \mathrm{H} \mathrm{H}_{2} \mathrm{O}$. No satisfactory explanation has been found for the increase in $\mathrm{A}-\mathrm{a} \mathrm{P}_{\mathrm{O}_{2}}$ gradient under anaesthesia but suggested causes include in- 
creased scatter of $\dot{V} / \dot{Q}$ ratios, shunt effect due to alveolar collapse, reduced cardiac output and increased alveolar $\mathrm{P}_{\mathrm{O}_{2}}$. It has also been suggested that the reduction of FRC below the closing volume is a possible causative factor. ${ }^{14}$

\section{CONCLUSION}

Nigerian patients were ventilated using the Magill attachment in situations which occur in normal clinical practice. No attempt was made to control the ventilatory volumes. Reliance for adequacy of ventilation was placed entirely on the trained hands of the anaesthetists. In all the cases results of blood gas analysis were within normal limits and compared favourably with patients who breathed spontaneously using the same circuit. Further studies will be necessary to determine the limits of usefulness with special reference to elderly patients and patients with chronic lung disease; but the results of our investigation in these few cases indicate that for young healthy Nigerian patients the Magill attachment is adequate for controlled ventilation using normal flows $(91 / \mathrm{min})$.

\section{SUMMARY}

Nine patients under anaesthesia were controlled manually with the Magill attachment. Nine other patients using the same circuit under anaesthesia breathed spontaneously. Blood gases were studied throughout the period of operation to determine the adequacy of ventilation. The results show that the Magill attachment was adequate for controlled ventilation using normal flows $(9 \mathrm{l} / \mathrm{min})$ in young healthy patients.

\section{RÉSUMÉ}

L'objet de ce travail était d'évaluer le rendement du circuit de Magill utilisé en respiration contrôlée, ceci dans le cadre de la pratique clinique normale. Dix huit patients du centre hospitalier de l'Université de Benin ont fait l'objet de cette étude; ces malades ont subi des interventions diverses.

Neuf des malades ont été laissés en ventilation spontanée avec un débit de gaz de $91 / \mathrm{min}$ et les neuf autres ont été ventilés de façon manuelle avec le même débit de gaz par minute.

L'on n'a pas fait de mesure des volumes respiratoires et c'est à "la main éduquée" des anesthésistes que l'on a laissé la responsabilité de fournir une ventilation adéquate. Des échantillons sanguins sériés ont été faits pour gazométries.

Les chiffres obtenus ont été normaux, à savoir des moyennes de $40.5 \mathrm{~mm} \mathrm{Hg}$ pour la $\mathrm{Pa}_{\mathrm{CO}_{2}}$, de $152.8 \mathrm{~mm} \mathrm{Hg}$ pour la $\mathrm{Pa}_{\mathrm{O}_{2}}$ et de 7.41 pour le $\mathrm{pH}$. Les résultats étaient comparables chez les malades en respiration spontanée et chez ceux en respiration contrôlée.

En discussion, les auteurs traitent des facteurs contribuant à l'élimination du $\mathrm{CO}_{2}$ avec le circuit de Magill et ils concluent que chez le patient jeune et en bon état, le circuit de Magill permet de fournir une ventilation contrôlée adéquate. 


\section{ACKNOWLEDGMENTS}

We would like to acknowledge the help and co-operation of the members of the Departments of Surgery and Obstetrics and Gynaecology. Our thanks go particularly to Dr. F.I. Iweze and Prof. L.N. Ajabor. We must also thank our Secretary, Mrs. C.A. Alile, for her help in preparing this paper.

\section{REFERENCES}

1. Mapleson, W.W. The elimination of rebreathing in various semi-closed anaesthetic systems. Brit. J. Anaesth. 26: 323 (1954).

2. Woolmen, R. \& Lind, B, Rebreathing with a semi-closed system. Brit. J. Anaesth. 26: 316 (1954).

3. Davies, R.M., Vermer, J.R., \& Bhacken, A. Carbon dioxide elimination from semi-closed systems. Brit. J. Anaesth. 28: 196 (1956).

4. SYKes, M.K. Rebreathing during controlled respiration with the Magill attachment. Brit. J. Anaesth. 31: 247 (1959).

5. Marshal, M. \& Henderson, G.A. Positive pressure ventilation using a semi-closed system: A re-assessment. Brit. J. Anaesth. 40: 265 (1968).

6. Nunn, J.F. Applied respiratory physiology Butterworth and Co. (Publishers) Ltd. pp. 306 (1969).

7. Salvatore, A.J., Sullivan, S.F., \& Papper, E.M. Post-operative hypoventilation and hypoxaemia in man after hyperventilation. New Eng. J. Med. 280: 467-70 (1969).

8. SugrokA, K. \& Davies, D.A. Hyperventilation with oxygen: a possible cause of cerebra] hypoxia. Anesthesiology 21: 135 (1960).

9. Wollman, H., Alexander, S.C., Cohen, P.J., Smith, T.C., Chase, P.E., \& vander Mollen, R.A. Cerebral circulation during general anaesthesia and hyperventilation in man. Anesthesiology 26: 329 (1965).

10. Camphell, E.J.M., Nunn, J.F., \& Peckett, B.W. A comparison of artificial ventilation and spontaneous respiration with particular reference to ventilation-blood flow relationships. Brit. J. Anaesth. 30: 166 (1958).

11. Colgan, F.J. \& Whang, T.B. Anaesthesia and atelectasis. Anesthesiology 29; 917 (1968).

12. Marshal, B.E., Cohen, P.J., Clingenmaier, C.H., \& Ankberg, S. Pulmonary venous admixture before, during and after halothane: oxygen anaesthesia in man. J. appl. Physiol. $27: 653$ (1969).

13. Panday, J. \& NunN, J.F. Failure to demonstrate progressive falls of arterial $P_{\mathrm{O}_{2}}$ during anaesthesia. Anaesthesia 23: 38 (1968).

14. LAwS, A.K. Effect of induction of anaesthesia and muscle paralysis on FRC of the lungs. Can. Anaesth. Soc. J. 15: 325 (1968). 